\title{
SELF-EFFICACIES OF PROSPECTIVE MATHEMATIC TEACHERS' TECHNOLOGICAL PEDAGOGICAL CONTENT KNOWLEDGE (TPACK)
}

\author{
Gaguk Resbiantoro \\ College of Education, STKIP PGRI Tulungagung, East Java, INDONESIA \\ gaguk@stkippgritulungagung.ac.id
}

\begin{abstract}
The purpose of this research was to describe the general self-efficacies of prospective teachers about TPACK based on gender and the types of internship school. This study was conducted to 55 prospective teachers that had finished their internship program at 18 schools, junior high schools, senior high schools, and vocational high schools. Data were collected through questionnaires, observations, and interviews. Questionnaires consist of statements on each TPACK component with the rating scale of 0-10. The result showed that self-efficacies of each TPACK component are 6,97 for TK, 5,71 for CK; 6,49 for PK; 6,95 for PCK; 6,38 for TCK; 6,05 for TPK; and 5,90 for TPACK; there are significant differences self-efficacies at TK and PCK component between male and female of prospective teachers, with the female one has a higher self-efficacies than the male one; there are significant difference self-efficacies at CK and TPACK component between the prospective teacher that have done an internship program at junior high schools, senior high schools, and vocational high schools.
\end{abstract}

Keywords: technological pedagogical content knowledge, self-efficacy

\begin{abstract}
Abstrak. Penelitian ini bertujuan untuk mengetahui deskripsi self-efficacy TPACK mahasiswa sebagai calon guru secara umum, deskripsi berdasarkan jenis kelamin dan tempat magang mahasiswa. Penelitian dilakukan pada 55 mahasiswa yang telah melaksanakan program magang di 18 sekolah yaitu SMP, SMA, dan SMK. Data penelitian dikumpulkan melalui angket, observasi, dan wawancara. Instrumen angket terdiri dari pernyataan pada setiap komponen TPACK dengan skala nilai 0-10. Hasil penelitian menunjukkan bahwa self-efficacy masing-masing komponen TPACK adalah 6,97 untuk TK; 5,71 untuk CK; 6,49 untuk PK; 6,95 untuk PCK; 6,38 untuk TCK; 6,05 untuk TPK; dan 5,90 untuk TPACK; terdapat perbedaan yang signifikan pada self-efficacy komponen TK dan PCK antara mahasiswa laki-laki dan perempuan, dengan keyakinan mahasiswi lebih tinggi dari pada mahasiswa tentang penguasaan komponen tersebut; terdapat perbedaan yang signifikan pada selfefficacy komponen CK dan TPACK antara mahasiswa magang di SMP, SMA, dan $S M K$.
\end{abstract}

Kata kunci: technological pedagogical content knowledge, self-efficacy

\section{Introduction}

Teachers have an important role in learning. The teacher's roles are an information provider, a role model, facilitator, assessor, planner, and resources developer
(Harden \& Crosby, 2000)and in the clinical context; (2. The teacher must have the characteristics (personal insight, changing insight, job management, document orderly) and competence (teaching skills and social 
communication) to play their roles (Chan, 2001)followed by characteristics related to professional predispositions. Personal attributes were rated as least important. Implications for the education of teachers of the gifted are discussed. (Contains references.. Teachers must have a good relationship with the students, especially in academic things at school. A good relationship can help the student to expand their knowledge and motivation in overcoming academic issues (Melorose, Perroy, \& Careas, 2003; Phillippo \& Stone, 2013). That means, teachers should be able to understand the psychology development and characteristics of students (Aquino, 2015). The overall of teacher's competence are formulated in the models of knowledge.

The development of information and communication technologies (ICT) affect on educational issues, particularly in term of literacy and learning media. ICT helps teachers to get information resources, to support creative and collaborative learning, improve the learning quality, and obtain teaching materials (Fu, 2013). Computer Assisted Instruction (CAI) was effective in supporting learning process (Eng, 2005). Teacher's capability to integrate ICT in learning depends on their ICT knowledge and PCK (Singh, 2013). Both of that knowledge must should be owned by teachers to create the creative and collaborative learning.

Models of teachers knowledge have introduced by Shulman (1986), that is pedagogical content knowledge (PCK), intersection of content knowledge (CK) and pedagogy knowledge (PK). Every component of PCK affect each others. Teachers have be able to integrate the pedagogy knowledge for teach specific topics to realize the effective learning (Gess-Newsome, 1999). PCK is described in five component, learning orientation of science, knowledge of curriculum, student's level of understanding about specific topic, assessment, and learning strategies (Magnusson, Krajcik, \& Borko, 1999). Math teachers also must have that components, subject matter knowledge, mathematical representation, understanding of students, and learning strategies (Fennema \& Franke, 1992).

Modelsofknowledge thatshouldbeowned by teacher has changed with the addition of technological knowledge component. Figure $\mathrm{I}$ is the relationship models between pedagogy knowledge (PK), content knowledge (CK), and technological knowledge (TK) in the framework of Technological Pedagogical Content Knowledge (TPACK) (Mishra \& Koehler, 2006). TPACK is a slice of PK, CK, and TK (Hsu, 2015a). CK is an organization of knowledge about subject matter (Harris, Mishra, \& Koehler, 2009; Koehler \& Mishra, 2009; Mishra \& Koehler, 2006; Shulman, 1986). PK is a knowledge about learning strategies and classroom management (Shulman, 1987). PK consist of knowledge about learning plan, classroom management, student assessment, student's learning styles, and learning practices (Harris et al., 2009; Koehler \& Mishra, 2008, 2009; Mishra \& Koehler, 2006). TK refers to all about technology and its use (Benson, Ward, \& Liang, 2015; Harris et al., 2009; Koehler \& Mishra, 2009; Mishra \& Koehler, 2006). TK related to digital technology, that is use of computers (software, hardware, internet, etc.) (Tzavara \& Komis, 2015).

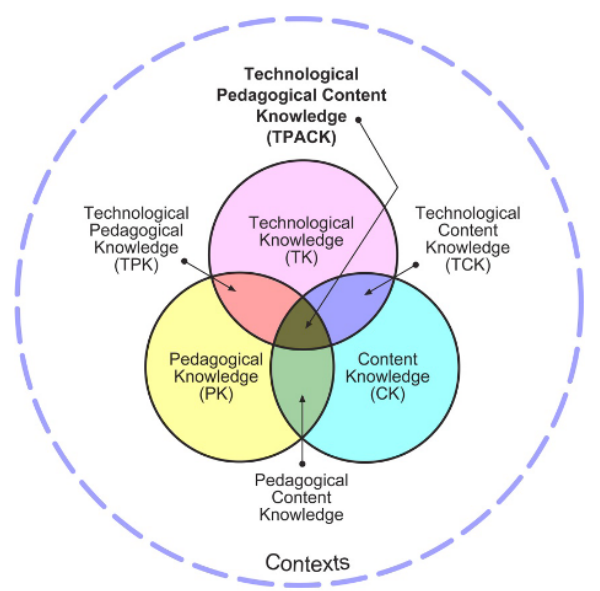

Figure 1: Models of TPAC Component Relationship, consist of TK, PK, CK as Primary Components (Koehler \& Mishra, 2009) 
The slices components of TK, PK, and CK respectively compose TCK, TPK, PCK, and TPACK. PCK is knowledge of the way to teach a specific subject matter according to both of characteristics, students and subject matter (Gess-Newsome, 1999; Magnusson, Krajcik, \& Borko, 2002; Shulman, 1986, 1987). TCK is related to subject matter knowledge and the use of technology to deepening and presentation of subject matter (Benton-Borghi, 2015; Harris et al., 2009; Kazu \& Erten, 2014; Koehler \& Mishra, 2008, 2009; Mishra \& Koehler, 2006; Tzavara \& Komis, 2015). TPK is the use of technology to support learning methods (Benton-Borghi, 2015; Harris et al., 2009; Koehler \& Mishra, 2008, 2009; Mishra \& Koehler, 2006; Terpstra, 2015).

TPACK is a framework of teacher knowledge which can support the teachers to implement effective learning. Teachers should be know how to teach the specific concepts with the use of technology (Benson et al., 2015; Benton-Borghi, 2015; Harris et al., 2009; Hsu, 2015a; Kazu \& Erten, 2014; Koehler \& Mishra, 2008, 2009; Mishra \& Koehler, 2006; Terpstra, 2015; Tzavara \& Komis, 2015). TPACK make the teachers understand about characteristics of subject matters and students, so they can choose the appropriate of learning strategies and the use of technology in learning.

Teacher's experiences and personal beliefs are very influential in the integration of technology in education (Angeli \& Valanides, 2009). In this case, self-efficacy are personal beliefs that affect on the way to achieve the learning aims and fostering students (Delahunty, 2016). Self-efficacy use to assess self-ability in the way to achieve the aims (Bandura, 1977)whatever their form, alter the level and strength of selfefficacy. It is hypothesized that expectations of per-sonal efficacy determine whether coping behavior will be initiated, how much effort will be expended, and how long it will be sustained in the face of ob-stacles and aversive experiences. Persistence in activities that are subjectively threatening but in fact relatively safe produces, through experiences of mastery, further enhancement of self-efficacy and corresponding reductions in defensive behavior. In the proposed model, expectations of personal efficacy are derived from four principal sources of information: performance accomplishments, vicarious experience, verbal persuasion, and physiological states. The more de-pendable the experiential sources, the greater are the changes in perceived self-efficacy. A number of factors are identified as influencing the cognitive processing of efficacy information arising from enactive, vicarious, exhortative, and emotive sources. The differential power of diverse therapeutic procedures is analyzed in terms of the postulated cognitive mechanism of operation. Findings are reported from microanalyses of enactive, vicarious, and emotive modes of treatment that support the hypothesized relationship between perceived self-efficacy and be-havioral changes. Possible directions for further research are discussed. Current developments in the field of behavioral change reflect two major divergent trends. The difference is especially evident in the treatment of dysfunctional inhibitions and defensive behavior. On the one hand, the mechanisms by which human behavior is acquired and regulated are increasingly formulated in terms of cognitive processes. On the other hand, it is performance-based procedures that are proving to be most powerful for effecting psychological changes. As a con-sequence, successful performance is replacing symbolically based experiences as the prin-ciple vehicle of change. The present article presents the view that changes achieved by different methods derive from a common cognitive mechanism. The", "author" : [ \{ "dropping-particle": “", "family”: "Bandura”, "given" : "Albert", "non-dropping-particle" : "”, "parse-names" : false, "suffix" : “" \} ], "container-title" : "Psychological Review", "id" : "ITEM-1", "issue" : "2", "issued" : \{ "date-parts" : [ [ "1977" ] ] \}, "page" : 
"191-215", "title" : "Self-efficacy: Toward a Unifying Theory of Behavioral Change", "type" : "article-journal", "volume" : "84" \}, "uris" : [ "http://www.mendeley.com/ documents/?uuid=ee921e23-521c-408aaf83-2b461d609fb4" ] \} ], "mendeley" : \{ "formattedCitation" : "(Bandura, 1977 and a powerful predictor of motivation and performance (Bandura, 1999). The student performance as prospective teachers about TPACK mastering needs to know for the evaluation and reflection of internship program. The data of TPACK mastering are collected from self-efficacies of prospective teachers. The purposes of this research was to describe the general self-efficacies of prospective teachers about TPACK; based on gender and the types of internship school.

\section{Method}

Self-efficacies of TPACK are collected with the cross-sectional survey method. This method appropriate to use because according to Creswell (2012) cross-sectional survey method can collect data efficiently and effectively. The population of this research is all of prospective mathematics teachers that have been done the internship program. There are 55 prospective mathematics teachers of the Department of Mathematics Education on the colleges in Tulungagung, East Java, Indonesia as sample of this research.

Table 1: Classification and Distribution of Sample Based on Gender and Internship Schools

\begin{tabular}{llc}
\hline \multicolumn{1}{c}{ Gender } & N & Percentage \\
\hline Male & 20 & 36.36 \\
Female & 35 & 63.64 \\
Internship School & & \\
Junior High School & 18 & 32.72 \\
Senior High School & 18 & 32.72 \\
Vocational High School & 19 & 34.56 \\
\hline
\end{tabular}

Classification of the sample are shown in Table 1. There are 35 female students and 20 male students from 3 types of internship schools that are 18 persons on junior high school (JHS), 18 persons on senior high school (SHS), and 19 on vocational high school (VHS). This research is conducted in academic year 2015/2016.

Instrument in this research is adapted the instruments of TPACK survey from Schmidt et al. (2009) with the measurement range from Bandura (2006)1997. This instrument is a questionnaire with 38 statements on the 7 factors TPACK (TK, PK, CK, PCK, TCK, TPK, and TPACK). The scoring of this instrument use self-efficacy scale from Bandura that is 0 to 10 (higher value is the higher self-efficacy). KMO's coefficient from this instrument is 0.91 and the result of Bartlett test indicate significance at the 0.05 level $(p=0.001)$. The coefficient of internal consistency from Alpha Cronbach is 0.96 for all items. Validity and reliability of the contents from this instrument have been tested by previous researcher so that did test again.

The techniques of data processing use the descriptive statistics (mean, percentage, and standard deviation) and use the comparison tests (Mann-Whitney U Test and KruskalWallis Test) for each sample classifications based on gender and internship school. The comments of each value of self-efficacies are "strongly disagree" on a range $0-2.6$, "disagree" on a range 2.7-5.2, "doubt" on a range 5.3-6.8, "agree" on a range 6.9-8.4, and "strongly agree" on a range $8.5-10$.

\section{Findings}

Data from the questionnaire are grouped within each component of TPACK, that is mean and standard deviation each item on every components. The summaries of result in each TPACK components are presented on 
Figure 2. According that figure, most of the prospective teachers are "doubt" on reveal their self-efficacies of TPACK. They reveal "agree" for the self-efficacies of PCK and $\mathrm{TK}$, but in the least value on the range.

Mean and standard deviation of selfefficacies on TK component are presented in Table 2. This component have 10 item of statements about mastering of technology from the prospective teachers. TK have 6.97 mean value with 0.69 standard deviation. The values stated that prospective teachers reveal "agree" about their mastery of technology, especially which is related with learning.

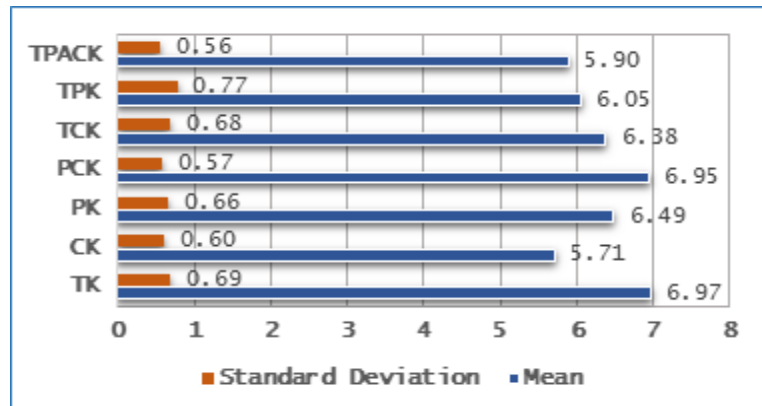

Figure 2: Mean and Standard Deviation on Each Component of TPACK

Table 2: Mean and Standard Deviation of Each Item in Technological Knowledge (TK)

\begin{tabular}{|c|c|c|}
\hline Statement of Technological Knowledge (TK) & Mean & SD \\
\hline Capability to solve the technically problem on computer. & 5.74 & 0.62 \\
\hline Understanding the basic component of computer. & 6.86 & 0.74 \\
\hline Capability of learn with the use of technology. & 6.70 & 0.59 \\
\hline Understanding of the technology development. & 6.33 & 0.62 \\
\hline Use of software to processing the words. & 6.91 & 0.73 \\
\hline Use of software to processing the numeral values. & 6.44 & 0.54 \\
\hline Use of software to presentation. & 7.29 & 0.69 \\
\hline Use of printer, scanner, camera, and projector. & 6.86 & 0.67 \\
\hline Communication through an internet. & 8.14 & 0.77 \\
\hline Use of computer/laptop as a data storage. & 8.46 & 0.95 \\
\hline Total & 6.97 & 0.69 \\
\hline
\end{tabular}

Table 3: Mean and Standard Deviation of Each Item in Content Knowledge (CK)

\begin{tabular}{lcc}
\hline \multicolumn{1}{c}{ Statement of Content Knowledge (CK) } & Mean & SD \\
\hline $\begin{array}{l}\text { Understanding of the mathematical concepts well. } \\
\begin{array}{l}\text { Understanding of the contextual mathematics and the other fields } \\
\text { study. }\end{array}\end{array}$ & 6.44 & 0.50 \\
$\begin{array}{l}\text { Capability to make visualization and simulation of the mathematical } \\
\text { concepts for learning and research. }\end{array}$ & 5.37 & 0.55 \\
$\begin{array}{l}\text { Activity of seminar and the others participation about scientific } \\
\text { mathematics. }\end{array}$ & 4.52 & 0.59 \\
$\begin{array}{l}\text { The use of newest books or journal to update mathematical } \\
\text { knowledge. }\end{array}$ & 5.90 & 0.61 \\
$\begin{array}{l}\text { Knowledge of the mathematical development. } \\
\text { Total }\end{array}$ & 5.74 & 0.51 \\
\hline
\end{tabular}

Table 3 presents the mean and standard deviation of self-efficacies on each item of $\mathrm{CK}$ components. This component have 6 item of statements about mastering of mathematics subject matter from the prospective teachers.
CK have 5.71 mean value with 0.60 standard deviation. The values stated that prospective teachers reveal "doubt" about their mastery of mathematics subject matter. 
As presented on Table 4, self-efficacies of PK component have 6.49 mean and 0.61 standard deviation. This component have 6 item of statements about mastery the pedagogy of mathematics learning from the prospective teachers. The values stated that prospective teachers reveal "doubt" about their mastery the pedagogy of mathematics learning.
Mean and standard deviation of selfefficacies on PCK component are presented in Table 5. This component have 4 item of statements about mastering of the way to teach a specific subject matter from the prospective teachers. PCK have 6.95 mean value with 0.57 standard deviation. The values stated that prospective teachers reveal "agree" about their mastery of the way to teach a specific subject matter.

Table 4: Mean and Standard Deviation of Each Item in Pedagogical Knowledge (PK)

\begin{tabular}{lcc}
\hline \multicolumn{1}{c}{ Statement of Pedagogical Knowledge (PK) } & Mean & SD \\
\hline Knowledge of the assessment. & 6.70 & 0.63 \\
Capability of the student assessment with comprehensive aspects and varied techniques. & 6.28 & 0.69 \\
Capability to apply the various learning strategies. & 6.38 & 0.58 \\
Capability to find the indications of learning difficulties and misconceptions. & 5.90 & 0.53 \\
Knowledge of the classroom management. & 6.70 & 0.59 \\
Capability to do reflective activity to improve learning quality. & 6.97 & 0.66 \\
\hline \multicolumn{1}{c}{ Total } & 6.49 & 0.61 \\
\hline
\end{tabular}

Table 5: Mean and Standard Deviation of Each Item in Pedagogical Content Knowledge (PCK)

\begin{tabular}{|c|c|c|}
\hline Statement of Pedagogical Content Knowledge (PCK) & Mean & SD \\
\hline $\begin{array}{l}\text { Capability to choose the suitable learning strategies for the characteristics of } \\
\text { mathematical subject matter. }\end{array}$ & 6.60 & 0.53 \\
\hline Capability to compose the learning plan. & 7.66 & 0.60 \\
\hline Capability to make the mathematical concepts easier. & 6.65 & 0.60 \\
\hline $\begin{array}{l}\text { Capability to construct the test for measure the student understanding of } \\
\text { mathematical concepts. }\end{array}$ & 6.91 & 0.56 \\
\hline Total & 6.95 & 0.57 \\
\hline
\end{tabular}

Table 6: Mean and Standard Deviation of Each Item in Technological Content Knowledge (PCK)

\begin{tabular}{lcc}
\hline \multicolumn{1}{c}{ Statement of Technological Content Knowledge (TCK) } & Mean & SD \\
\hline The use of technology to support the understanding of mathematical concepts. & 6.06 & 0.74 \\
Knowledge of computer application that related to mathematics. & 6.76 & 0.55 \\
Capability to develop the student activity and task that involving the use of & 5.48 & 0.68 \\
computer. & 7.23 & 0.76 \\
$\begin{array}{l}\text { The use of internet application to deepen knowledge and to update the } \\
\text { information about mathematics. } \quad \text { Total }\end{array}$ & 6.38 & 0.68 \\
\hline
\end{tabular}

Table 6 presents the mean and standard deviation of self-efficacies on each item of TCK components. This component have 4 item of statements about the use of technology to explore and present the subject matter by the prospective teachers. TCK have 6.38 mean value with 0.68 standard deviation. The values stated that prospective teachers reveal "doubt" about the use of technology to explore and present the subject matter.

As presented on Table 7, self-efficacies of TPK component have 6.05 mean and 0.77 
standard deviation. This component have 4 item of statements about the use of technology in the mathematics learning generally by the prospective teachers. The values stated that prospective teachers reveal "doubt" about the use of technology in the mathematics learning generally.

Table 7: Mean and Standard Deviation of Each Item in Technological Pedagogical Knowledge (PCK)

\begin{tabular}{lcc}
\hline \multicolumn{1}{c}{ Statement of Technological Pedagogical Knowledge (TPK) } & Mean & SD \\
\hline The use of computer/laptop in learning. & 6.12 & 0.93 \\
Capability to choose the use of technology that suitable for learning approach and & 5.90 & 0.74 \\
strategies. & 7.02 & 0.82 \\
Knowledge of internet base of communication (social media, blog, web, etc.) & 5.16 & 0.60 \\
\hline Knowledge of e-learning concepts. $\quad$ Total & 6.05 & 0.77 \\
\hline
\end{tabular}

Table 8: Mean and Standard Deviation of Each Item in Technological Pedagogical Content Knowledge (TPACK)

\begin{tabular}{|c|c|c|}
\hline Statement of Technological Pedagogical Content Knowledge (TPACK) & Mean & SD \\
\hline $\begin{array}{l}\text { Knowledge to choose the learning strategies and the use of technology that suitable for } \\
\text { mathematical subject matter characteristics. }\end{array}$ & 6.12 & 0.54 \\
\hline $\begin{array}{l}\text { Capability to integrate mathematical knowledge, pedagogical knowledge, and } \\
\text { technological knowledge to realize the effective learning. }\end{array}$ & 5.43 & 0.52 \\
\hline $\begin{array}{l}\text { Capability to help the peers to integrate mathematical knowledge, pedagogical } \\
\text { knowledge, and technological knowledge to realize the effective learning. }\end{array}$ & 6.01 & 0.54 \\
\hline $\begin{array}{l}\text { Capability about various implementation of the learning strategies and technology in the } \\
\text { mathematical learning. }\end{array}$ & 6.06 & 0.62 \\
\hline Total & 5.90 & 0.56 \\
\hline
\end{tabular}

Table 8 presents the mean and standard deviation of self-efficacies on each item of TPACK components. This component have 4 item of statements about the use of technology to teach a specific subject matter in mathematics by the prospective teachers. TPACK have 5.9 mean value with 0.56 standard deviation. The values stated that prospective teachers reveal "doubt" about the use of technology to teach a specific subject matter in mathematics.

The result of comparison test for TPACK components based on gender are presented in Table 9. Data distribution was not normal from the result of normality test. For that condition, Mann-Whitney U Test was used instead of t-test. There are significant difference was determined between selfefficacies of TK $(U=57.000, p<0.05)$ and PCK
$(U=43.000, p<0.05)$ based on the variable of gender. According to this finding, the female of prospective teachers have higher levels of self-efficacy on using technology and the way to teach a specific matter.

Table 10 presents the result of comparison test each TPACK components according to internship school. Data was processed by Kruskal-Wallis test to find out the difference levels of self-efficacy. The result showed that there are significant difference of $\mathrm{CK}(\mathrm{CS}=6.400, \mathrm{p}<0.05)$ and TPACK $(C S=10.267, p<0.05)$. According to this finding, the prospective teachers who have conducted the internship program on junior high school, have a higher levels of self-efficacy on subject matter knowledge and the use of technology to teach a specific subject matter in mathematics. 
Table 9: Result of Mann-Whitney U Test for Self-efficacies of Prospective Teachers about TPACK based on Gender

\begin{tabular}{|c|c|c|c|c|c|c|}
\hline Component & Gender & $\mathbf{N}$ & Mean Rank & Sum of Rank & $\mathbf{U}$ & $\mathbf{p}$ \\
\hline \multirow{2}{*}{$T K$} & Female & 35 & 19.72 & 493.00 & \multirow{2}{*}{57.000} & \multirow{2}{*}{$0.021 *$} \\
\hline & Male & 20 & 11.33 & 102.00 & & \\
\hline \multirow{2}{*}{$C K$} & Female & 35 & 17.90 & 447.50 & \multirow{2}{*}{102.500} & \multirow{2}{*}{0.686} \\
\hline & Male & 20 & 6.39 & 147.50 & & \\
\hline \multirow{2}{*}{$P K$} & Female & 35 & 18.32 & 458.00 & \multirow{2}{*}{92.000} & \multirow{2}{*}{0.401} \\
\hline & Male & 20 & 15.22 & 137.00 & & \\
\hline \multirow{2}{*}{$P C K$} & Female & 35 & 20.28 & 507.00 & \multirow{2}{*}{43.000} & \multirow{2}{*}{$0.040^{*}$} \\
\hline & Male & 20 & 9.78 & 88.00 & & \\
\hline \multirow{2}{*}{$T C K$} & Female & 35 & 17.80 & 445.00 & \multirow{2}{*}{105.000} & \multirow{2}{*}{0.763} \\
\hline & Male & 20 & 16.67 & 150.00 & & \\
\hline \multirow{2}{*}{$T P K$} & Female & 35 & 17.66 & 441.50 & \multirow{2}{*}{108.500} & \multirow{2}{*}{0.868} \\
\hline & Male & 20 & 17.06 & 153.50 & & \\
\hline \multirow{2}{*}{ TPACK } & Female & 35 & 17.86 & 446.50 & \multirow{2}{*}{103.500} & \multirow{2}{*}{0.689} \\
\hline & Male & 20 & 16.50 & 148.50 & & \\
\hline
\end{tabular}

$* \mathrm{p}<0.05$

Table 10: Result of Kruskal-Wallis Test for Self-efficacies of Prospective Teachers about TPACK based on Internship School

\begin{tabular}{|c|c|c|c|c|c|}
\hline Component & Internship School & $\mathbf{N}$ & Mean Rank & Chi-Square & $\mathbf{p}$ \\
\hline \multirow{3}{*}{$T K$} & SHS & 18 & 18.36 & & \\
\hline & VHS & 19 & 15.46 & 0.907 & 0.635 \\
\hline & JHS & 18 & 18.86 & & \\
\hline \multirow{3}{*}{$C K$} & SHS & 18 & 8.00 & & \\
\hline & VHS & 19 & 12.42 & 6.400 & $0.041^{*}$ \\
\hline & JHS & 18 & 22.55 & & \\
\hline \multirow{3}{*}{$P K$} & SHS & 18 & 18.23 & & \\
\hline & VHS & 19 & 15.54 & 0.820 & 0.664 \\
\hline & JHS & 18 & 18.91 & & \\
\hline \multirow{3}{*}{$P C K$} & SHS & 18 & 13.50 & & \\
\hline & VHS & 19 & 20.96 & 3.602 & 0.165 \\
\hline & JHS & 18 & 17.73 & & \\
\hline \multirow{3}{*}{ TCK } & SHS & 18 & 15.27 & & \\
\hline & VHS & 19 & 17.67 & 1.083 & 0.582 \\
\hline & JHS & 18 & 19.55 & & \\
\hline \multirow{3}{*}{$T P K$} & SHS & 18 & 19.05 & & \\
\hline & VHS & 19 & 14.04 & 2.557 & 0.278 \\
\hline & JHS & 18 & 19.73 & & \\
\hline \multirow{3}{*}{ TPACK } & SHS & 18 & 12.14 & & \\
\hline & VHS & 19 & 16.25 & 10.267 & $0.006^{*}$ \\
\hline & JHS & 18 & 24.23 & & \\
\hline
\end{tabular}

$* \mathrm{p}<0.05$ 


\section{Discussion}

According to overall data description of self-efficacies, the prospective teachers still "doubt" with their TPACK. It is reasonable because the prospective teachers need a lot of teaching experience. Most of the prospective teachers concede that they still nervous in first experience of teaching. They also still feel difficult to manage the class. The competence of TPACK will grow in step with that experiences. More and teaching experience, the greater efficacy of mastering TPACK (Kazu \& Erten, 2014; Joyce Hwee Ling Koh, Chai, \& Tsai, 2014).

The prospective teachers feel quite confident about their technological knowledge. This statement is in accordance with the conditions of this technological era. Most of people have used the information technology, especially in youth. It is also appropriate with the statement from Betül and Mehmet Fatih (2011)natural phenomena and mechanisms by creating technology-rich environments (TRE, that is the prospective teachers feel quite confident in the use of technology in the teaching and learning. According the seventh item on Table 2, the level of self-efficacy is high (mean value $=$ 7.29) about the use of presentation software as a learning media. They feel confused to solve the technical problems of computer because it needs the special skill to do it.

The CK competence of the prospective teachers need to improve for supporting the PCK and TPACK (Robert \& Margaret, 2005). $\mathrm{CK}$ is very important because it is the core knowledge for every mathematical subject matters. This became the basic knowledge to know all of mathematical context (Aslantutak \& Adams, 2015). According the third item on Table 3 , the prospective teachers have a weakness about simulation and visualization of mathematical concepts in learning. This condition is caused by the less active of prospective teacher participation on seminars about scientific mathematics. This means that the prospective teachers do not follow the development of scientific mathematics.
PK is the important thing to development of teacher professionalism. In generally, the prospective teachers feel "doubt" about their PK competence. The prospective teachers have a weakness to find the indications of learning difficulties and misconceptions on students. This is appropriate with the fourth item in Table 4. The prospective teacher indecision is good as the reason to develop their competence, because the concern is they do not aware that still lacking in the mastering of PK (Hsu, 2015b). The development of PK competence is not only affected by the teaching experience, but should be through the training programs (Dicke et al., 2014; Lauermann \& König, 2016).

According second item of Table 5, the prospective teachers are quite confident to compose the learning plan. This condition should be happen to the prospective teachers that have done the internship program because they have got a lot of theories about learning plan (Hadiprayitno, et. al, 2016). The prospective teachers are quite capable to manage the learning strategy that appropriate to subject matter characteristics. PCK component is affected by $\mathrm{CK}$ competence that is about mastering of the mathematical subject matter (Turnuklu \& Yesildere, 2007).

The prospective teachers have a most activity to use internet as a media for develop of CK mastering. In other hand they have a weakness to develop the student activity that related to computer. This is caused by the less of their knowledge and the lack of computer facilities in internship schools. Generally, the prospective teachers are quite confident about computer application that related to mathematical concepts. This condition prove that the prospective teachers are confident to use mathematical software (Stoilescu, 2015).

TPK is focused on the use of technology to support the learning strategies. The prospective teacher knowledge of e-learning concept is weak, as well as the ability to choose technology that supports their learning strategies. This condition should be reduced 
with increasing the frequency of technology integration in lectures at colleges. It can familiarize the prospective teachers with technology-based learning (Singh, 2013).

The overall of TPACK competence, the self-efficacies of prospective teachers have a low level. They still not sure about their ability to integrate mathematical concepts, learning strategies, student assessment, and the use of technology that appropriate with second item in Table 8. As the prospective teacher, this condition is caused by the lack of experiences. They have to develop the TPACK competence continuously both before and after entering their jobs (Akman \& Guven, 2015; Chai, Koh, Tsai, \& Tan, 2011; Kiray, 2016; J. H L Koh, Chai, \& Tsai, 2010)"type" : "article-journal", "volume" : "2" \}, "uris" : [ "http://www.mendeley.com/ documents $/$ ?uuid $=9$ f8f6690-b660-4bebbc05-346eaca21257" ] \}, \{ “id" : “ITEM2", “itemData" : \{ "author" : [ \{ "droppingparticle" : "', "family" : "Kiray", "given" : "Seyit Ahmet", "non-dropping-particle" : “", "parse-names" : false, "suffix" : “" \} ], "container-title" : "International Journal of Research in Education and Science (IJRES.

According Table 9, there are significant difference between the component of TK and PCK on the male and female of prospective teachers. In generally, there are significant difference between TPACK of male and female teachers (Erdogan \& Sahin, 2010; Kazu \& Erten, 2014). The result presented that the female teachers have higher level of selfefficacy than the male one. This conditions is caused by the achievement index of female prospective teachers are better than the male one in the college. So, according that indicator, the female of prospective teachers have more a material readiness to perform in an internship program.

The prospective teachers have performed an internship program in 3 types of schools that are junior high school (JHS), senior high school (SHS), and vocational high school (VHS). According to the Table 10, there are significant difference between self-efficacies level of prospective teachers at JHS, SHS, and VHS. The difference are CK and TPACK component. The prospective teachers who have done the internship program at JHS, have a higher level of self-efficacies on CK and TPACK component. Most of the prospective teachers concede that the subject matter in SHS and VHS more difficult than in JHS, so that they feel less confident. On the VHS, they feel "doubt" to explore their TPACK competence. This condition is caused by the students are accustomed with the integration of technology in daily learning, while the prospective teachers are not accustomed to do that.

\section{Conclusion}

According the result of research, selfefficacies of each TPACK component are 6,97 for TK, 5,71 for CK; 6,49 for PK; 6,95 for PCK; 6,38 for TCK; 6,05 for TPK; and 5,90 for TPACK; there are significant differences selfefficacies at TK and PCK component between male and female of prospective teacher, with the female one have a higher self-efficacies than the male one; there are significant differences self-efficacies at CK and TPACK component between the prospective teacher that have done an internship program at junior high schools, senior high schools, and vocational high schools. In generally, the TPACK competence of prospective teacher have to develop continuously to become a professional teachers.

The results have presented a description of prospective teacher's TPACK. There are several things need to be observed in more depth. This study can be follow up to evaluate the implementation of an internship program related to the college student preparation. The training program and accustom the integration of technology in learning can be trying to do. The further research about every component of TPACK should be conducted. Misconceptions of student colleges, evaluating TPACK, and the others way about increasing TPACK competence are allows to become a topic of further research. 


\section{References}

Akman, O. and, \& Guven, C. 2015. Analysis of TPACK Self-Efficacy Perception Levels of Social Studies Teachers and Pre-Service Teachers. International Journal of Contemporary Educational Research, 2(1), 1-12.

Angeli, C., \& Valanides, N. 2009. Epistemological and methodological issues for the conceptualization, development, and assessment of ICT-TPCK: Advances in technological pedagogical content knowledge (TPCK). Computers and Education, 52(1), 154-168.

Aquino, A. B. 2015. Self-efficacy on Technological, Pedagogical and Content Knowledge (TPACK) of Biological Science Pre-Service Teachers. Asia Pacific Journal of Multidisciplinary Research, 3(4), 150-157.

Aslan-tutak, F., \& Adams, T. L. 2015. A Study of Geometry Content Knowledge of Elementary Preservice Teachers. International Electronic Journal of Elementary Education, 7(3), 301-318.

Bandura, A. 1977. Self-efficacy: Toward a Unifying Theory of Behavioral Change. Psychological Review, 84(2), 191-215.

Bandura, A. 1999. Social Cognitive Theory: An Agentic Perspective. Asian Journal of Social Psychology, 2, 21-41.

Bandura, A. 2006. Guide for constructing self-efficacy scales. In F. Pajares \& T. Urdan (Eds.), Self-Efficacy Beliefs of Adolescents (pp. 307-337). Greenwich: Information Age Publishing.

Benson, S. N. K., Ward, C. L., \& Liang, X. 2015. The Essential Role of Pedagogical Knowledge in Technology Integration for Transformative Teaching and Learning. In C. Angeli \& N. Valanides (Eds.), Technological Pedagogical Content Knowledge: Exploring, Developing, and Assessing TPCK (pp. 3-18). New York: Springer Science+Business Media.

Benton-Borghi, B. H. 2015. Intersection and Impact of Universal Design for Learning (UDL) and Technological, Pedagogical, and Content Knowledge (TPACK) on Twenty-First Century Teacher Preparation: UDL-Infused TPACK Practitioner's Model. In C. Angeli \& N. Valanides (Eds.), Technological Pedagogical Content Knowledge: Exploring, Developing, and Assessing TPCK (pp. 287-304). New York: Springer Science+Business Media.

Betül, T., \& Mehmet Fatih, T. 2011. In-Service Science Teachers' Technological Pedagogical Content Knowledge Confidences and Views about Technology-Rich Environments. CEPS Journal : Center for Educational Policy Studies Journal, 1(4), 11.

Chai, C. S., Koh, J. H. L., Tsai, C.-C., \& Tan, L. L. W. 2011. Modeling primary school pre-service teachers' Technological Pedagogical Content Knowledge (TPACK) for meaningful learning with information and communication technology (ICT). Computers and Education, 57(1), 1184-1193.

Chan, D. W. 2001. Characteristics and competencies of teachers of gifted learners: The Hong Kong teacher perspective. Roeper Review, 33(3), 160-169.

Creswell, J. W. 2012. Educational research: Planning, conducting, and evaluating quantitative and qualitative research. Educational Research (4th ed., Vol. 4). Washington, D.C.: SAGE Publications. 
Delahunty, J. 2016. Book Review: Fostering Self-Efficacy in Higher Education Students. Journal of University Teaching \& Learning Practice, 13(1).

Dicke, T., Parker, P. D., Marsh, H. W., Kunter, M., Schmeck, A., \& Leutner, D. 2014. Selfefficacy in classroom management, classroom disturbances, and emotional exhaustion: A Moderated mediation analysis of teacher candidates. Journal of Educational Psychology, 106(2), 569-583.

Eng, T. S. 2005. The impact of ICT on learning: A review of research. International Education Journal, 6(5), 635-650. Retrieved from http://iej.cjb.net

Erdogan, A., \& Sahin, I. 2010. Relationship between math teacher candidates' Technological Pedagogical And Content Knowledge ( TPACK ) and achievement levels. Procedia Social and Behavioral Sciences, 2(2), 2707-2711.

Fennema, E., \& Franke, M. 1992. Teachers' knowledge and its impact. In D. A. Grouws (Ed.), Handbook of Research on Mathematics Teaching and Learning. New York: Macmillan Publishing.

Fu, J. S. 2013. ICT in Education: A Critical Literature Review and Its Implications. International Journal of Education and Development Using Information and Communication Technology, 9(1), 112-125.

Gess-Newsome, J. 1999. Pedagogical Content Knowledge: An Introduction and Orientation. In J. Gess-Newsome \& N. G. Lederman (Eds.), Examining Pedagogical Content Knowledge: The Construct and its Implications for Science Education (pp. 3-17). Dordrecht: Kluwer Academic Publishers. Retrieved from

Hadiprayitno, G., Ramdani, A., Jamaluddin, Karnan, \& Sukri, A. 2016. Kompetensi Profesional dan Pedagogi Mahasiswa dalam Pelaksanaan Program Pengalaman Lapangan. Cakrawala Pendidikan, XXXV(2), 292-300.

Harden, R. M., \& Crosby, J. R. 2000. The Good Teacher is More Than A Lecturer. Medical Teacher, 22(4), 334-347. https://doi.org/10.1080/014215900409429

Harris, J., Mishra, P., \& Koehler, M. 2009. Teachers ' Technological Pedagogical Content Knowledge and Learning Activity Types : Curriculum-based Technology Integration Reframed. Journal of Research on Technology in Education, 41(4), 393-416.

Hsu, Y.-S. 2015a. The Development of Teachers' Professional Learning and Knowledge. In Y.-S. Hsu (Ed.), Development of Science Teachers' TPACK: East Asian Practices (pp. 3-15). Singapore: Springer Science+Business Media.

Hsu, Y.-S. 2015b. The Development of Teachers' Professional Learning and Knowledge. Development of Science Teachers' TPACK: East Asian Practices.

Kazu, I. Y., \& Erten, P. 2014. Teachers' Technological Pedagogical Content Knowledge SelfEfficacies. Journal of Education and Training Studies, 2(2), 126-144.

Kiray, S. A. 2016. Development of a TPACK Self-Efficacy Scale for Preservice Science Teachers. International Journal of Research in Education and Science (IJRES), 2(1), $527-541$.

Koehler, M. J., \& Mishra, P. 2008. Introducing TPCK. In AACTE Committee on Innovation and Technology (Ed.), Handbook of Technological Pedagogical Content Knowledge TPCK for Educators (pp. 3-29). New York: AACTE and Routledge.

Koehler, M. J., \& Mishra, P. 2009. What is Technological Pedagogical Content Knowledge (TPACK)? Contemporary Issues in Technology and Teacher Education, 9, 60-70. 
Koh, J. H. L., Chai, C. S., \& Tsai, C. 2014. Demographic Factors, TPACK Constructs ,and Teachers' Perceptions of Constructivist-Oriented TPACK. Educational Technology \& Society, 17(1), 185-196.

Koh, J. H. L., Chai, C. S., \& Tsai, C. C. 2010. Examining the technological pedagogical content knowledge of Singapore pre-service teachers with a large-scale survey. Journal of Computer Assisted Learning, 26(6), 563-573.

Lauermann, F., \& König, J. 2016. Teachers' professional competence and wellbeing: Understanding the links between general pedagogical knowledge, self-efficacy and burnout. Learning and Instruction, 45, 9-19.

Magnusson, S., Krajcik, J., \& Borko, H. 1999. Nature, Sources and Development of Pedagogical Content Knowledge for Science Teaching. In J. Gess-Newsome \& N. G. Lederman (Eds.), Examining Pedagogical Content Knowledge: The Construct and its Implications for Science Education (pp. 95-132). Dordrecht: Kluwer Academic Publishers.

Magnusson, S., Krajcik, J., \& Borko, H. 2002. Nature, Sources and Development of Pedagogical Content Knowledge for Science Teaching. In J. Gess-Newsome \& N. G. Lederman (Eds.), Examining Pedagogical Content Knowledge: The Construct and its Implications for Science Education (pp. 95-132). New York: Kluwer Academic Publishers.

Melorose, J., Perroy, R., \& Careas, S. 2003. Case Studies of Teacher Development. New Jersey: Lawrence Erlbaum Associates.

Mishra, P., \& Koehler, M. J. 2006. Technological Pedagogical Content Knowledge : A Framework for Teacher Knowledge. Teachers College Record, 108(6), 1017-1054.

Phillippo, K. L., \& Stone, S. 2013. Teacher Role Breadth and its Relationship to StudentReported Teacher Support. The High School Journal, 96(4), 358-379.

Robert, M., \& Margaret, M. 2005. The Mathematics Content Knowledge Role in Developing Preservice Teachers 'Pedagogical Content Knowledge. Journal of Research in Childhood Education, 20(2), 102-118.

Schmidt, D. A., Baran, E., Thompson, A. D., Koehler, M. J., Mishra, P., \& Shin, T. 2009. Technological Pedagogical Content Knowledge (TPACK): The Development and Validation of an Assessment Instrument for Preservice Teachers. Journal of Research on Technology in Education, 42(2), 123-149. Retrieved from http://www.sjrbiz.info/ Webliography Lists/TPACK Survey.pdf

Shulman, L. S. 1986. Those Who Understand: Knowledge Growth in Teaching. Educational Researcher, 15(2), 4-14.

Shulman, L. S. 1987. Knowledge and Teaching: Foundations of the New Reform. Harvard Educational Review, 57(1), 1-21.

Singh, U. 2013. Technology Integration in Teacher Education : an Infusion or a Delusion? Journal of Arts, Science \& Commerce, IV(3), 147-155.

Stoilescu, D. 2015. A Critical Examination of the Technological Pedagogical Content Knowledge Framework: Secondary School Mathematics Teachers Integrating Technology. Journal of Educational Computing Research, 52(4), 514-547.

Terpstra, M. 2015. TPACKtivity: An Activity-Theory Lens for Examining TPACK Development. In C. Angeli \& N. Valanides (Eds.), Technological Pedagogical Content Knowledge: Exploring, Developing, and Assessing TPCK (pp. 63-88). New York: Springer Science+Business Media. 
Turnuklu, E. B., \& Yesildere, S. 2007. The Pedagogical Content Knowledge in Mathematics: Pre- Service Primary Mathematics Teachers' Perspectives in Turkey. IUMPST: The Journal, 1(October), 1-13.

Tzavara, A., \& Komis, V. 2015. Design and Implementation of Educational Scenarios with the Integration of TDCK: A Case Study at a Department of Early Childhood Education. In C. Angeli \& N. Valanides (Eds.), Technological Pedagogical Content Knowledge: Exploring, Developing, and Assessing TPCK (pp. 209-224). New York: Springer Science+Business Media. 